\title{
Venom-Derived Peptide Modulators of Cation-Selective Channels: Friend, Foe or Frenemy
}

\author{
Saumya Bajaj ${ }^{\star \dagger}$ and Jingyao Han ${ }^{\dagger}$ \\ Lee Kong Chian School of Medicine, Nanyang Technological University, Singapore, Singapore
}

Ion channels play a key role in our body to regulate homeostasis and conduct electrical signals. With the help of advances in structural biology, as well as the discovery of numerous channel modulators derived from animal toxins, we are moving toward a better understanding of the function and mode of action of ion channels. Their ubiquitous tissue distribution and the physiological relevancies of their opening and closing suggest that cation channels are particularly attractive drug targets, and years of research has revealed a variety of natural toxins that bind to these channels and alter their function. In this review, we provide an introductory overview of the major cation ion channels: potassium channels, sodium channels and calcium channels, describe their venom-derived peptide modulators, and how these peptides provide great research and therapeutic value to both basic and translational medical research.

Alexander A. Vassilevski, Institute of Bioorganic Chemistry (RAS), Russia

Reviewed by:

Steve Peigneur,

KU Leuven, Belgium

José Javier López Barba, Universidad de Extremadura, Spain Christian Legros,

Université d'Angers, France

*Correspondence:

Saumya Bajaj

saumya.bajaj@ntu.edu.sg

${ }^{\dagger}$ These authors have contributed equally to this work

Specialty section:

This article was submitted to Pharmacology of Ion Channels and Channelopathies, a section of the journal

Frontiers in Pharmacology

Received: 16 June 2018

Accepted: 18 January 2019

Published: 26 February 2019

Citation:

Bajaj S and Han J (2019) Venom-Derived Peptide Modulators of Cation-Selective Channels: Friend,

Foe or Frenemy.

Front. Pharmacol. 10:58 doi: 10.3389/fphar.2019.00058

\section{INTRODUCTION}

Cone snails whose shells are coveted for their elaborate patterns, yellow dart frogs measuring just a few centimeters long, and transparent bell-shaped jellyfish with delicate tentacles might all seem unlikely candidates, but they are among the deadliest animals in the world. Like the more obvious perilous creatures - venomous snakes, spiders and scorpions - these animals release toxins that dramatically modulate the activity of various targets including ion channels, thereby affecting cellular communication and disrupting normal biochemical and physiological processes in prey or predator.

Animal venom is a complex mixture of various components - inorganic salts, organic molecules like alkaloids, proteins and peptides (King, 2011). While this concoction enables a multi-pronged attack upon the target organism, it has also led to an entire collection of bio-active compounds being available to researchers for probing the structural and functional properties of their molecular targets. Since ion channels play an essential role in neuronal signaling and muscle contractions, it is unsurprising that many venom toxins have evolved to block or modulate the function of ion channels (Dutertre and Lewis, 2010). Not only have venom-derived peptides been used extensively in probing ion channels, the understanding of the mechanism of this interaction has also led to the development of venom-based therapeutics targeting various ion channels. In fact, the recognition of animal venom having medicinal benefits is not a recent phenomenon. Venom from various animals had been used as medicines for centuries, in civilizations all over the world (Bhattacharjee and Bhattacharyya, 2014; Utkin, 2015).

Modern medicine has shown conclusively that venoms contain compounds with therapeutic potential. Many of these have been isolated, analyzed for structure and function, and have served as scaffolds for the development of various drugs. Venom peptides have evolved to be highly stable, being able to withstand degradation by proteolytic enzymes in the foreign environment they are 
injected into and in the venom itself. This stability is conferred by one or more disulfide bridges (Figure 1). While the peptides mutate into more potent and/or selective variants, the structurally important cysteines tend to be highly conserved. Cystine-stabilized $\alpha / \beta$ fold, inhibitor cystine knot (ICK, or knottin) and the three-finger toxin motif are all highly prevalent motifs in these peptides (Undheim et al., 2016).

This mini-review briefly describes exemplar peptides derived from animal venom, which have been used to probe the structure and function of voltage-activated cation channels, as well as are being developed as potential therapeutics (listed in Table 1). Here, we describe ion channels that are selectively permeable to potassium, calcium, and sodium ions.

\section{VENOM PEPTIDES TARGETING POTASSIUM CHANNELS}

Potassium ion channels are of high therapeutic value due to their broad and active presence in a variety of human tissue. To date, numerous disease conditions in neuronal, cardiac, immune, and endocrine systems have been reported to be directly associated with malfunction of potassium channels. Potassium channels are categorized into four families: two transmembrane (TM) Kir channels, four TM, two pore-domain K2P channels, and six $\mathrm{TM} \mathrm{K}_{\mathrm{v}}$ and $\mathrm{K}_{\mathrm{Ca}}$ channels (Chuan et al., 2013). Here, we discuss the Kir, $\mathrm{K}_{\mathrm{v}}$ and $\mathrm{K}_{\mathrm{Ca}}$ channels. The $\mathrm{K} 2 \mathrm{P}$ family of channels contribute to voltage-independent "leak" $\mathrm{K}^{+}$current, and are structurally different from other classes of $\mathrm{K}^{+}$channels in that they assemble as 'dimer of dimers' (Goldstein et al., 2005). No venom-derived peptide toxins have been reported for K2P channels yet (McQueen, 2017).

Inwardly rectifying potassium (Kir) channels were first described in 1949 in frog skeletal muscles (Katz, 1949), however, they were not cloned and isolated until 1993 (Ho et al., 1993;

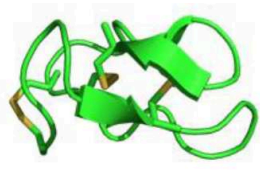

$\Omega$-conotoxin MVIIA

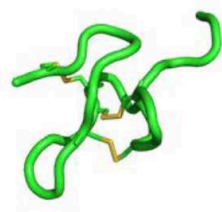

ProTX-II

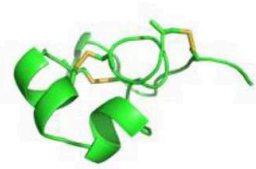

ShK

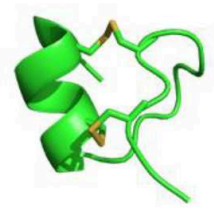

TPNQ
FIGURE 1 | Structures of venom-derived peptide toxins - clockwise from top-left: $\omega$-conotoxin MVIIA (PDB: 1MVI), ShK (PDB: 1ROO), TPNQ (PDB: 1TER), and ProTX-II (PDB: 2N9T). Disulfide linkages are shown in yellow.
Kubo et al., 1993). As the name suggests, Kir channels inwardly rectify outward $\mathrm{K}^{+}$current, allowing extracellular $\mathrm{K}^{+}$to readily flow into the cells. The unique molecular mechanism is due to the intracellular binding of $\mathrm{Mg}^{2+}$ and polyamines (Lu, 2004). Kir channels are homo- or hetero- tetrameric structures assembled from four Kir subunits, containing two TM segments separated by a selectivity filter region (Whorton and MacKinnon, 2011; Li et al., 2017). Structural, functional and pathophysiological details of four specific types of Kir channels have been detailed elsewhere (Hibino et al., 2010).

The peptides that show high affinity toward Kir channels $\left(\mathrm{IC}_{50}<0.5 \mu \mathrm{M}\right)$ are scorpion toxin ChTx2 $(\alpha-\mathrm{KTx} 1.2)$, snake toxin $\delta$-dendrotoxin $(\delta$-DTX), and honey bee toxin Tertiapin (TPN) (Lu and MacKinnon, 1997; Imredy et al., 1998; Jin and Lu, 1998; Doupnik, 2017). Like many other venom toxins, these three molecules are rich in cysteine and positively charged residues. Computational simulation and docking studies have hypothesized binding mechanisms of these toxins ( $\mathrm{Li}$ et al., 2016). Positively charged residues from toxin come into close contact with negatively charged residues on channel pore region, strengthening electrostatic interactions between the two. Hydrophobic forces between aliphatic residues also count into binding affinity.

TPN and TPN $\mathrm{M}_{13 \mathrm{Q}}$ are considered the most potent inhibitors. TPN binds to Kir1.1 and Kir3.1/3.4 at 2-8 nM (EC $\left.\mathrm{E}_{50}\right)$, thus being an ideal tool for investigations of Kir channels' functional and pharmacological properties (Dobrev et al., 2005; Walsh, 2011). TPN has shown potential therapeutic use in a canine model, treating atrial fibrillation, without causing ventricle arrhythmia (Hashimoto et al., 2006). More recently, TPN, together with sodium channel blockers, has been shown to have synergistic effects in preventing atrial fibrillation and prolonging atrial effective refractory period. The combination formula has been patented for medication manufacturing by Gilead Sciences.

Voltage-gated potassium $\left(\mathrm{K}_{\mathrm{V}}\right)$ channels tightly control membrane permeability of $\mathrm{K}^{+}$by sensing voltage change, thereby playing a key role in regulating action potential and propagating electrical signals in excitable cells (Yellen, 2002). In non-excitable cells, $\mathrm{K}_{\mathrm{v}}$ channels modulate cellular metabolism and facilitate downstream signaling cascade; for example, $\mathrm{K}_{\mathrm{v}} 1.3$ in T lymphocytes (Cahalan and Chandy, 2009). $40 \mathrm{~K}_{\mathrm{v}}$ channels in 12 subfamilies have been found and many extensively studied (Alexander et al., 2017). $\mathrm{K}_{\mathrm{V}}$ channels are homo- or heterotetramers, made up of four subunits each consisting of six TM helices. Voltage sensing domain (VSD) (S1-S4) is connected to pore domain (S5-S6) through S4-S5 intracellular loop, driving the pore to open or close (Long et al., 2005).

Research on venom peptide modulators of $\mathrm{K}_{\mathrm{V}}$ channels started in 1980s, and to date more than 200 peptides with inhibitory effect on $\mathrm{K}_{\mathrm{v}}$ channels have been identified (Carbone et al., 1982; Kuzmenkov et al., 2016). These polypeptides usually bind to $\mathrm{K}_{\mathrm{v}}$ channels in two unique mechanisms. The pore blockers sit in the shallow vestibule at extracellular pore region, while the gating modifiers bind to the so-called "paddle motif" of the VSD accessible from the extracellular side.

Scorpion toxin charybdotoxin (ChTx) was one of the earliest venom toxins used as an important research tool to understand 
TABLE 1 | Venom-derived peptide modulators of cation channels.

\begin{tabular}{|c|c|c|c|c|}
\hline Channel & Toxin & Species & $\mathrm{IC}_{50} / K_{\mathrm{d}}$ & Reference \\
\hline & $\delta$-DTX & Dendroaspis angusticeps & $150 \mathrm{nM}$ & Imredy et al., 1998 \\
\hline Kir3.1/Kir3.4 & Tertiapin (TPN) & Apis mellifera & $8 \mathrm{nM}$ & Jin and Lu, 1998 \\
\hline \multirow[t]{5}{*}{$\mathrm{K}_{\mathrm{v}} 1.1$} & $\alpha-D T x$ & Dendroaspis angusticeps & $20 \mathrm{nM}$ & Grissmer et al., 1994 \\
\hline & DTx K (toxin I) & Dendroaspis polylepis & $50 \mathrm{nM}$ & Robertson and Owen, 1993 \\
\hline & $\alpha-K T \times 2.5$ (hongotoxin) & Centruroides limbatus & $31 \mathrm{pM}$ & Koschak et al., 1998 \\
\hline & $\alpha-K T \times 3.13$ & Mesobuthus eupeus & 203 pM & Gao et al., 2010 \\
\hline & ShK & Stichodactyla helianthus & $16 \mathrm{pM}$ & Kalman et al., 1998 \\
\hline \multirow[t]{9}{*}{$\mathrm{K}_{\mathrm{v}} 1.2$} & $\alpha$-DTx & Dendroaspis angusticeps & $17 \mathrm{nM}$ & Grissmer et al., 1994 \\
\hline & $\alpha-K T \times 1.1$ (Charybdotoxin) & Leiurus quinquestriatus hebraeus & $9 \mathrm{nM}$ & Takacs et al., 2009 \\
\hline & $\alpha-K T \times 10.1$ (Cobatoxin-1) & Centruroides noxius & $27 \mathrm{nM}$ & Jouirou et al., 2004 \\
\hline & $\alpha-K T \times 3.6$ (mesomartoxin) & Mesobuthus martensii & $15 \mathrm{nM}$ & Wang et al., 2015 \\
\hline & $\alpha-K T \times 6.4$ & Pandinus imperator & $8 \mathrm{pM}$ & Sarrah et al., 2003 \\
\hline & $\alpha-K T x-6.2$ (Maurotoxin) & Scorpio maurus palmatus & $0.8 \mathrm{nM}$ & Ryadh et al., 2018 \\
\hline & $\alpha-K T x-6.21$ (Urotoxin) & Urodacus yaschenkoi & $160 \mathrm{pM}$ & Luna-Ramírez et al., 2014 \\
\hline & ShK & Stichodactyla helianthus & $9 \mathrm{nM}$ & Kalman et al., 1998 \\
\hline & BscTx1 & Bunodosoma caissarum & $30 \mathrm{pM}$ & Orts et al., 2013 \\
\hline \multirow[t]{6}{*}{$\mathrm{K}_{\mathrm{v}} 1.3$} & $\alpha-K T \times 6.12$ (Anuroctoxin) & Anuroctonus phaiodactylus & $0.73 \mathrm{nM}$ & Bagdáany et al., 2005 \\
\hline & $\alpha-K T x 3.12($ Aam-KTX) & Androctonus amoreuxi & $1.1 \mathrm{nM}$ & Abbas et al., 2008 \\
\hline & $\alpha-K T \times 2.1$ (Noxiustoxin) & Centruroides noxius & $1 \mathrm{nM}$ & Grissmer et al., 1994 \\
\hline & $\alpha-K T \times 2.2$ (margatoxin) & Centruroides margaritatus & $11 \mathrm{pM}$ & Bartok et al., 2014 \\
\hline & $\alpha-K T \times 2.5$ (hongotoxin) & Centruroides limbatus & $86 \mathrm{nM}$ & Koschak et al., 1998 \\
\hline & ShK & Stichodactyla helianthus & $11 \mathrm{pM}$ & Kalman et al., 1998 \\
\hline \multirow[t]{5}{*}{$\mathrm{K}_{\mathrm{v}} 1.6$} & $\alpha-D T x$ & Dendroaspis angusticeps & $9 \mathrm{nM}$ & Swanson et al., 1990 \\
\hline & $\alpha-K T x 1.1$ (Charybdotoxin) & Leiurus quinquestriatus hebraeus & $22 \mathrm{nM}$ & Garcia et al., 1994 \\
\hline & $\alpha-K T \times 3.2$ (Agitoxin-2) & Leiurus quinquestriatus hebraeus & $37 \mathrm{pM}$ & Garcia et al., 1994 \\
\hline & ShK & Stichodactyla helianthus & $165 \mathrm{pM}$ & Kalman et al., 1998 \\
\hline & BcSTx1/BcSTx2 & Bunodosoma caissarum & $1.3 \mathrm{nM} / 7.7 \mathrm{nM}$ & Orts et al., 2013 \\
\hline \multirow[t]{3}{*}{$\mathrm{K}_{\mathrm{v}} 2.1$} & HaTx1 (Hanatoxin) & Grammostola spatulata & $42 \mathrm{nM}$ & Swartz and MacKinnon, 1995 \\
\hline & JZTX-III/JZTX-XI & Chilobrachys jingzhao & $710 \mathrm{nM} / 390 \mathrm{nM}$ & Tao et al., 2013, 2016 \\
\hline & ScTx1 & Stromatopelma calceata & $12.7 \mathrm{nM}$ & Escoubas et al., 2002 \\
\hline$K_{v} 2.2$ & ScTx1 & Stromatopelma calceata & $21.4 \mathrm{nM}$ & Escoubas et al., 2002 \\
\hline $\mathrm{K}_{\mathrm{v}} 3.2$ & ShK & Stichodactyla helianthus & $6 \mathrm{nM}$ & Yan et al., 2005 \\
\hline$K_{v} 3.4$ & BDS-I/BDS-II & Anemonia sulcata & $47 \mathrm{nM} / 56 \mathrm{nM}$ & Diochot et al., 1998 \\
\hline $\mathrm{K}_{\mathrm{v}} 4.1$ & JZTX-XII & Chilobrachys jingzhao & $363 \mathrm{nM}$ & Yuan et al., 2007 \\
\hline \multirow[t]{5}{*}{$\mathrm{K}_{\mathrm{v}} 4.2$} & PaTx1/PaTx2 & Phrixotrichus auratus & $5 \mathrm{nM} / 34 \mathrm{nM}$ & Diochot et al., 1999 \\
\hline & ScTx1 & Stromatopelma calceata & $1.2 \mathrm{nM}$ & Escoubas et al., 2002 \\
\hline & TsTx-K $\beta$ (Ts8) & Tityus serrulatus & $652 \mathrm{nM}$ & Pucca et al., 2016 \\
\hline & HpTx3 (Heteropodatoxin) & Heteropoda venatoria & $67 \mathrm{nM}$ & Sanguinetti et al., 1997 \\
\hline & JZTX-V & Chilobrachys jingzhao & $604.2 \mathrm{nM}$ & Zeng et al., 2007 \\
\hline \multirow[t]{2}{*}{$K_{v} 4.3$} & PaTx1/PaTx2 & Phrixotrichus auratus & $28 \mathrm{nM} / 71 \mathrm{nM}$ & Diochot et al., 1999 \\
\hline & SNX-482 & Hysterocrates gigas & $3 \mathrm{nM}$ & Kimm and Bean, 2014 \\
\hline
\end{tabular}


TABLE 1 | Continued

\begin{tabular}{|c|c|c|c|c|}
\hline Channel & Toxin & Species & $\mathrm{IC}_{50} / K_{\mathrm{d}}$ & Reference \\
\hline & $\alpha-K T \times 1.3$ (Iberiotoxin) & Mesobuthus tamulus & $1.7 \mathrm{nM}$ & Candia et al., 1992 \\
\hline & $\alpha-K T x 1.6(B m T \times 2)$ & Buthus martensiKarsch & $0.3 \mathrm{nM}$ & Romi-Lebrun et al., 1997 \\
\hline & $\alpha-K T \times 1.11$ (Slotoxin) & Centruroides noxius & $1.5 \mathrm{nM}$ & Garcia-Valdes et al., 2001 \\
\hline & $\alpha-K T \times 3.1$ (Kaliotoxin) & Androctonus mauretanicus & $20 \mathrm{nM}$ & Crest et al., 1992 \\
\hline & $\alpha-K T x 12.1$ (Butantoxin) / TsTX-IV & Tityus serrulatus & $50 \mathrm{nM}$ & Novello et al., 1999 \\
\hline & $\alpha-K T x(B m P 09)$ & Buthus martensiKarsch & $27 \mathrm{nM}$ & Yao et al., 2005 \\
\hline & Natrin & Naja naja atra & $34.4 \mathrm{nM}$ & Wang et al., 2005 \\
\hline \multirow[t]{3}{*}{$\mathrm{K}_{\mathrm{Ca}} 2.1$} & $\alpha-K T \times 5.1$ (Leiurotoxin I/scyllatoxin) & Leiurus quinquestriatus hebraeus & $325 \mathrm{nM}$ & Castle and Strong, 1986 \\
\hline & Tamapin & Mesobuthus tamulus & $32 \mathrm{nM}$ & Pedarzani et al., 2002 \\
\hline & Apamin & Apis mellifera & $8 \mathrm{nM}$ & Hugues et al., 1982 \\
\hline & Apamin & Apis mellifera & $30-200 \mathrm{pM}$ & Hugues et al., 1982 \\
\hline & TsK & Tityus serrulatus & $80 \mathrm{nM}$ & Lecomte et al., 1999 \\
\hline \multirow[t]{5}{*}{$\mathrm{K}_{\mathrm{Ca}} 2.3$} & $\alpha-K T \times 5.1$ (Leiurotoxin I/scyllatoxin) & Leiurus quinquestriatus hebraeus & $1.1 \mathrm{nM}$ & Castle and Strong, 1986 \\
\hline & PO5 & Androctonus mauretanicus & $25 \mathrm{nM}$ & Zerrouk et al., 1993 \\
\hline & Tamapin & Mesobuthus tamulus & $1.7 \mathrm{nM}$ & Pedarzani et al., 2002 \\
\hline & Apamin & Apis mellifera & $10 \mathrm{nM}$ & Hugues et al., 1982 \\
\hline & Tsk & Tityus serrulatus & $197 \mathrm{nM}$ & Lecomte et al., 1999 \\
\hline \multirow[t]{4}{*}{$\mathrm{K}_{\mathrm{Ca}} 3.1$} & $\alpha-K T \times 1.1$ (Charybdotoxin) & Leiurus quinquestriatus hebraeus & $5 \mathrm{nM}$ & Ghanshani et al., 2000; Rauer et al., 2000 \\
\hline & $\alpha-K T \times 6.2$ (Maurotoxin) & Maurus palmatus & $1 \mathrm{nM}$ & Castle, 2003 \\
\hline & Margatoxin & Centruroides margaritatus & $459 \mathrm{nM}$ & Garcia-Calvo et al., 1993 \\
\hline & $\alpha-K T \times 3.7$ (OSK1) & Orthochirus scrobiculosus & $225 \mathrm{nM}$ & Mouhat et al., 2005 \\
\hline & AFT-II & Anthopleura fuscoviridis & $391 \mathrm{nM}$ & Oliveira et al., 2004 \\
\hline & GVIIJSSG & Conus geographus & $11 \mathrm{nM}$ & Gajewiak et al., 2014 \\
\hline & $\mu$-Conotoxin BulllA & Conus bullatus & $0.35 \mu \mathrm{M}$ & Wilson et al., 2011 \\
\hline \multirow[t]{16}{*}{$\mathrm{Na}_{\mathrm{v}} 1.2$} & Huwentoxin IV & Haplopelma schmidti & $150 \mathrm{nM}$ & Minassian et al., 2013 \\
\hline & ATX-II & Anemonia sulcata & $41 \mathrm{nM}$ & Oliveira et al., 2004 \\
\hline & Bc-III & Bunodosoma caissarum & $1449 \mathrm{nM}$ & Oliveira et al., 2004 \\
\hline & AFT-II & Anthopleura fuscoviridis & $1998 \mathrm{nM}$ & Oliveira et al., 2004 \\
\hline & Lqh-2 & Leiurus quinquestriatus hebraeus & $1.8 \mathrm{nM}$ & Chen et al., 2002 \\
\hline & PnTx1 & Phoneutria nigriventer & $33.7 \mathrm{nM}$ & Silva et al., 2012 \\
\hline & Phrixotoxin 3 (PaurTx3) & Phrixotrichus auratus & $0.6 \mathrm{nM}$ & Bosmans et al., 2006 \\
\hline & ProTx-III & Thrixopelma pruriens & $0.3 \mu \mathrm{M}$ & Cardoso et al., 2015 \\
\hline & Hainantoxin-IV & Ornithoctonus hainana & $36 \mathrm{nM}$ & Liu et al., 2003 \\
\hline & GrTx1 & Grammostola rosea & $0.23 \mu \mathrm{M}$ & Redaelli et al., 2010 \\
\hline & GVIIJSSG & Conus geographus & $11 \mathrm{nM}$ & Gajewiak et al., 2014 \\
\hline & $\mu$-conotoxin TIIIA & Conus tulipa & $0.045 \mu \mathrm{M}$ & Wilson et al., 2011 \\
\hline & $\mu$-conotoxin SIIIA & Conus striatus & $0.05 \mu \mathrm{M}$ & Wilson et al., 2011 \\
\hline & $\mu$-conotoxin KIIIA & Conus kinoshitai & $0.003 \mu \mathrm{M}$ & Wilson et al., 2011 \\
\hline & $\mu$-conotoxin MIIIA & Conus magus & $0.45 \mu \mathrm{M}$ & Wilson et al., 2011 \\
\hline & $\mu$-conotoxin BulllA & Conus bullatus & $0.012 \mu \mathrm{M}$ & Wilson et al., 2011 \\
\hline
\end{tabular}


TABLE 1 | Continued

\begin{tabular}{|c|c|c|c|c|}
\hline Channel & Toxin & Species & $\mathrm{IC}_{50} / K_{\mathrm{d}}$ & Reference \\
\hline & ATX-II & Anemonia sulcata & $759 \mathrm{nM}$ & Oliveira et al., 2004 \\
\hline & ProTx-III & Thrixopelma pruriens & $0.9 \mu \mathrm{M}$ & Cardoso et al., 2015 \\
\hline & Hainantoxin-IV & Ornithoctonus hainana & $375 \mathrm{nM}$ & Liu et al., 2003 \\
\hline & $\operatorname{GrTx1}$ & Grammostola rosea spider & $0.77 \mu \mathrm{M}$ & Redaelli et al., 2010 \\
\hline & $\mu$-conotoxin BulllA & Conus bullatus & $0.35 \mu \mathrm{M}$ & Wilson et al., 2011 \\
\hline \multirow[t]{8}{*}{$\mathrm{Na}_{v} 1.4$} & AFT-II & Anthopleura fuscoviridis & $31 \mathrm{nM}$ & Oliveira et al., 2004 \\
\hline & ATX-II & Anemonia sulcata & $109 \mathrm{nM}$ & Oliveira et al., 2004 \\
\hline & Bc-III & Bunodosoma caissarum & $821 \mathrm{nM}$ & Oliveira et al., 2004 \\
\hline & MrVIB ( $\mu$ O-Conotoxin) & Conus marmoreus & $222 \mathrm{nM}$ & Zorn et al., 2006 \\
\hline & MfVIA ( $\mu$ O-Conotoxin) & Conus magnificus & $81 \mathrm{nM}$ & Vetter et al., 2012 \\
\hline & $\mu$-conotoxin SIIIA & Conus striatus & $0.13 \mu \mathrm{M}$ & Wilson et al., 2011 \\
\hline & $\mu$-conotoxin MIIIA & Conus magus & $0.33 \mu \mathrm{M}$ & Wilson et al., 2011 \\
\hline & $\mu$-conotoxin BullIA & Conus bullatus & $0.012 \mu \mathrm{M}$ & Wilson et al., 2011 \\
\hline \multirow[t]{5}{*}{$\mathrm{Na}_{v} 1.5$} & ProTx-II & Thrixopelma pruriens & $79 \mathrm{nM}$ & Middleton et al., 2002 \\
\hline & ATX-II & Anemonia sulcata & $49 \mathrm{nM}$ & Oliveira et al., 2004 \\
\hline & AFT-II & Anthopleura fuscoviridis & $62.5 \mathrm{nM}$ & Oliveira et al., 2004 \\
\hline & Bc-III & Bunodosoma caissarum & $307 \mathrm{nM}$ & Oliveira et al., 2004 \\
\hline & CGTX-II & Bunodosoma cangicum & $50 \mathrm{nM}$ & Zaharenko et al., 2012 \\
\hline \multirow[t]{3}{*}{$\mathrm{Na}_{\mathrm{v}} 1.6$} & ATX-II & Anemonia sulcata & $180 \mathrm{nM}$ & Oliveira et al., 2004 \\
\hline & AFT-II & Anthopleura fuscoviridis & $300 \mathrm{nM}$ & Oliveira et al., 2004 \\
\hline & Bc-III & Bunodosoma caissarum & $900 \mathrm{nM}$ & Oliveira et al., 2004 \\
\hline & Lqh-2 & Leiurus quinquestriatus hebraeus & $32 \mathrm{nM}$ & Chen et al., 2002 \\
\hline & Lqh-3 & Leiurus quinquestriatus hebraeus & $13.6 \mathrm{nM}$ & Chen et al., 2002 \\
\hline & GpTx-1 & Grammostola porteri & $10 \mathrm{nM}$ & Murray et al., 2015 \\
\hline & $\mu$-SLPTX-Ssm6a & Scolopendra subspinipes mutilans & $25 \mathrm{nM}$ & Yang et al., 2013 \\
\hline & Hainantoxin-IV & Ornithoctonus hainana & $21 \mathrm{nM}$ & Liu et al., 2003 \\
\hline & $\mu-T R T x-P n 3 a$ & Pamphobeteus nigricolor & $0.9 \mathrm{nM}$ & Deuis et al., 2017 \\
\hline & GrTx1 & Grammostola rosea & $0.37 \mu \mathrm{M}$ & Redaelli et al., 2010 \\
\hline & GVIIJSSG & Conus geographus & $41 \mathrm{nM}$ & Gajewiak et al., 2014 \\
\hline & Huwentoxin-IV & Haplopelma schmidti & $26 \mathrm{nM} ; 0.4 \mathrm{nM}$ & Xiao et al., 2008; Rahnama et al., 2017 \\
\hline \multirow[t]{4}{*}{$\mathrm{Na}_{v} 1.8$} & ProTx-I & Thrixopelma pruriens & $27 \mathrm{nM}$ & Middleton et al., 2002 \\
\hline & MrVIB ( $\mu$ O-Conotoxin) & Conus marmoreus & $102 \mathrm{nM}$ & Ekberg et al., 2006 \\
\hline & MfVIA ( $\mu \mathrm{O}$-Conotoxin) & Conus magnificus & $529 \mathrm{nM}$ & Vetter et al., 2012 \\
\hline & HSTX-I & Haemadipsa sylvestris & $2.44 \mu \mathrm{M}$ & Wang et al., 2018 \\
\hline $\mathrm{Na}_{v} 1.9$ & HSTX-I & Haemadipsa sylvestris & $3.30 \mu \mathrm{M}$ & Wang et al., 2018 \\
\hline $\mathrm{Ca}_{v} 1.2$ & Calciseptine & Dendroaspis polylepis polylepis & $430 \mathrm{nM}$ & de Weille et al., 1991 \\
\hline \multirow[t]{5}{*}{$\mathrm{Ca}_{v} 2.1$} & $\omega$-conotoxin CVIB & Conus catus & $7.7 \mathrm{nM}$ & Lewis et al., 2000 \\
\hline & $\omega$-conotoxin CVIC & Conus catus & $7.6 \mathrm{nM}$ & Lewis et al., 2000 \\
\hline & $\omega$-conotoxin MVIIC & Conus magus & $7 \mathrm{nM}$ & Lewis et al., 2000 \\
\hline & $\omega$-agatoxin IVA & Agelenopsis aperta & $0.1 \mu \mathrm{M}$ & Mintz et al., 1992 \\
\hline & $\omega$-grammotoxin SIA & Grammostola rosea & $50 \mathrm{nM}$ & Lampe et al., 1993; McDonough et al., 1997 \\
\hline
\end{tabular}


TABLE 1 | Continued

\begin{tabular}{|c|c|c|c|c|}
\hline Channel & Toxin & Species & $\mathrm{IC}_{50} / K_{\mathrm{d}}$ & Reference \\
\hline \multirow[t]{11}{*}{$\mathrm{Ca}_{v} 2.2$} & $\omega$-agatoxin IIA & Agelenopsis aperta & $10 \mathrm{nM}$ & Bindokas and Adams, 1989; Adams et al., 1990 \\
\hline & $\omega$-agatoxin IIIA & Agelenopsis aperta & $1.4 \mathrm{nM}$ & Ertel et al., 1994; Olivera et al., 1994 \\
\hline & $\omega$-agatoxin IIIB & Agelenopsis aperta & $140 \mathrm{nM}$ & Ertel et al., 1994; Yan and Adams, 2000 \\
\hline & $\omega$-agatoxin IIID & Agelenopsis aperta & $35 \mathrm{nM}$ & Ertel et al., 1994 \\
\hline & $\omega$-ctenitoxin-Pn3a/Neurotoxin Tx3-4 & Phoneutria nigriventer & $50 \mathrm{pM}$ & Cordeiro Mdo et al., 1993 \\
\hline & $\omega$-conotoxin CVIA & Conus catus & $0.6 \mathrm{nM}$ & Lewis et al., 2000 \\
\hline & $\omega$-conotoxin CVIB & Conus catus & $7.7 \mathrm{nM}$ & Lewis et al., 2000 \\
\hline & $\omega$-conotoxin CVIC & Conus catus & $7.6 \mathrm{nM}$ & Lewis et al., 2000 \\
\hline & $\omega$-conotoxin CVID & Conus catus & $0.07 \mathrm{nM}$ & Lewis et al., 2000 \\
\hline & $\omega$-conotoxin MVIIA & Conus magus & $0.055 \mathrm{nM}$ & Lewis et al., 2000 \\
\hline & $\omega$-conotoxin GVIA & Conus geographus & $0.04 \mathrm{nM}$ & Olivera et al., 1984; Lewis et al., 2000 \\
\hline $\mathrm{Ca}_{\mathrm{v}} 2.3$ & SNX482 & Hysterocrates gigas & $15-30 \mathrm{nM}$ & Newcomb et al., 1998 \\
\hline \multirow[t]{2}{*}{$\mathrm{Ca}_{\mathrm{v}} 3.1$} & Kurtoxin & Parabuthus transvaalicus & $15-50 \mathrm{nM}$ & Chuang et al., 1998; Sidach and Mintz, 2002 \\
\hline & ProTx1 & Thrixopelma pruriens & $200 \mathrm{nM}$ & Ohkubo et al., 2010 \\
\hline Cav3.2 & Kurtoxin & Parabuthus transvaalicus & $25-50 \mathrm{nM}$ & Chuang et al., 1998; Sidach and Mintz, 2002 \\
\hline
\end{tabular}

$\mathrm{K}_{\mathrm{v}}$ channel subunit stoichiometry (MacKinnon, 1991), auxiliary beta subunits (Garcia et al., 1995), as well as its overall architecture (Hidalgo and MacKinnon, 1995).

Sea anemone toxin ShK blocks $\mathrm{K}_{\mathrm{V}}$ channels at nanomolar to sub-nanomolar potency (Castañeda et al., 1995; Kalman et al., 1998). ShK and its analogs are blockers of the $\mathrm{K}_{\mathrm{v}}$ channel pore. They bind to all four subunits in the channel tetramer by two key interactions within the external vestibule - Lys 22 occludes the channel pore like a "cork in a bottle," and Tyr23, together with Lys22, forms a "functional dyad" required for channel block. Many $\mathrm{K}^{+}$channel-blocking peptides exhibit similar blocking mechanism, consisting of a dyad of lysine and neighboring aromatic/aliphatic residue (Chang et al., 2018). With the goal of developing a highly selective $\mathrm{K}_{\mathrm{V}} 1.3$ inhibitor, nearly 10 years of effort was made to re-engineer the native ShK. In 2006, a stable analog, ShK-186 demonstrated specific binding to $\mathrm{K}_{\mathrm{v}} 1.3$ at 69 $\mathrm{pM}$, which is 100 -fold selective to other $\mathrm{K}_{\mathrm{v}}$ channels (Chi et al., 2012). ShK-186 (Dalazatide), now being developed by Kineta, has passed phase I clinical trials It is the only venom-derived peptide blocking $\mathrm{K}^{+}$channels that is being developed as a therapeutic (Tarcha et al., 2012, Tarcha et al., 2017).

The hERG channel (or $\mathrm{K}_{\mathrm{V}} 11.1$ ) plays a crucial role in the cardiac action potential by repolarizing $\mathrm{IKr}$ current, the rapid component of the delayed rectifier potassium current. While selective $\mathrm{K}_{\mathrm{v}}$ 11.1-blockers are available (e.g., BeKm-1 from scorpion Mesobuthus eupeus) (Korolkova et al., 2001), it warrants special attention as many drugs/peptides intended for other targets, can exhibit non-selective binding to it, with potentially fatal consequences. Inhibition of hERG by drugs can lead to lengthening of the electrocardiographic QT interval, while hERG channel activators can cause drug-induced short QT syndrome. Both cases can lead to potentially fatal arrhythmias. Hence, FDA guidelines recommend that all drugs that are intended for human use be evaluated for anti-hERG activity (Vandenberg et al., 2012).

Calcium $\left(\mathrm{Ca}^{2+}\right)$-activated potassium channels $\left(\mathrm{K}_{\mathrm{Ca}}\right)$ are broadly divided into three subtypes based on their single channel conductance - big conductance $\left(\mathrm{BK}_{\mathrm{Ca}}\right)$, intermediate conductance $\left(\mathrm{IK}_{\mathrm{Ca}}\right)$ and small conductance $\left(\mathrm{SK}_{\mathrm{Ca}}\right)$. While the $\mathrm{BK}_{\mathrm{Ca}}$ channels are activated by both voltage and increase in cytosolic $\mathrm{Ca}^{2+}$, the $\mathrm{IK}_{\mathrm{Ca}}$ and $\mathrm{SK}_{\mathrm{Ca}}$ channels are activated exclusively by the latter. Like $\mathrm{Kir}$ and $\mathrm{K}_{\mathrm{v}}$ channels, the $\mathrm{K}_{\mathrm{Ca}}$ channels are tetramers made up of four $\alpha$ subunits. $\mathrm{BK}_{\mathrm{Ca}}$ requires additional regulatory subunits, and is made up of $6 / 7$ TM segments, while $\mathrm{SK}_{\mathrm{Ca}}$ and $\mathrm{IK}_{\mathrm{Ca}}$ contain 6 TM segments, with a calmodulin molecule bound to each subunit, serving as the $\mathrm{Ca}^{2+}$ sensor. One of the first peptide toxins that were found to inhibit $\mathrm{K}^{+}$channels included apamin (derived from bee venom) and charybdotoxin (ChTX, derived from the scorpion venom) (Hugues et al., 1982; Rauer et al., 2000). Apamin blocks SK channels $\left(\mathrm{K}_{\mathrm{Ca}} 2\right)$, and served as a primary pharmacological tool to distinguish between $\mathrm{K}_{\mathrm{Ca}} 2$ channels and $\mathrm{K}_{\mathrm{Ca}} 1.1 / \mathrm{K}_{\mathrm{Ca}}$ 3.1. ChTX inhibits both $\mathrm{K}_{\mathrm{Ca}}$ channels $\left(\mathrm{K}_{\mathrm{Ca}} 1.1\right.$ and $\left.\mathrm{K}_{\mathrm{Ca}} 3.1\right)$ and $\mathrm{K}_{\mathrm{v}}$ channels $\left(\mathrm{K}_{\mathrm{v}} 1.2, \mathrm{~K}_{\mathrm{v}} 1.3\right.$, and $\left.\mathrm{K}_{\mathrm{v}} 1.6\right)$. Another scorpion toxin iberiotoxin is selective for $\mathrm{BK}$ channel $\left(\mathrm{K}_{\mathrm{Ca}} 1.1\right)$ (Candia et al., 1992).

\section{VENOM PEPTIDES TARGETING VOLTAGE-GATED SODIUM CHANNELS}

Voltage-gated sodium $\left(\mathrm{Na}_{\mathrm{v}}\right)$ channels are present in the membranes of most excitable cells and are responsible for initiation and propagation of action potentials. Studies elucidating details of ion selectivity, hypothesizing the $\mathrm{Na}_{\mathrm{V}}$ pore diameter and binding mechanism of sodium-channel acting local anesthetics and related drugs, were bolstered by the availability of ion channel toxins, like the alkaloids tetrodotoxin (TTX) and saxitoxin (STX) (Hille, 1971, 1975, 1977; Armstrong et al., 1973). Studies to isolate and purify the $\mathrm{Na}_{\mathrm{v}}$ channel protein were pioneered by William Catterall and co-workers using, besides TTX and STX, scorpion toxin (ScTx) neuropeptides (Agnew et al., 1978; Beneski and Catterall, 1980; Hartshorne and Catterall, 1981). 
$\mathrm{Na}_{\mathrm{v}}$ channels are divided into nine subtypes $\left(\mathrm{Na}_{\mathrm{v}} 1.1-\mathrm{Na}_{\mathrm{v}} 1.9\right)$ based on their sequence, TTX binding and tissue expression. The $250 \mathrm{kDa}$ channel-forming $\alpha$-subunits are pseudo-tetrameric, wherein a single polypeptide chain folds into four homologous, non-identical domains (DI-IV), each containing six TM segments (S1-S6). The S5-S6 segments from all four domains form the central ion pore, while the S1-S4 segments in each domain form the VSD. A single channel is composed of one poreforming $\alpha$ subunit, which may be associated with either one or two $\beta$ subunits. The $\alpha$ subunit is functional on its own, and forms the core of the channel.

The venom of various animals contain toxins that target $\mathrm{Na}_{\mathrm{v}}$ channels to attack the neuromuscular systems of their adversaries and prey. Toxins that modulate $\mathrm{Na}_{\mathrm{v}}$ channel function generally do so in two ways - either by blocking the flow of $\mathrm{Na}^{+}$ions through the pore, or by modifying the gating mechanisms.

One of the best studied pore blockers for $\mathrm{Na}_{\mathrm{v}}$ channels are the $\mu$-conotoxin peptides from cone snails. Conotoxins are disulfiderich peptides that are isolated from the venom of cone snails (genus Conus). Venom derived from cone snails is a treasure trove of peptide toxins for different ion channels and other receptor proteins (Olivera et al., 1985, 1990). M-conotoxins demonstrate the best binding with the skeletal muscle isoform of $\mathrm{Na}_{\mathrm{v}}$ channel, $\mathrm{Na}_{\mathrm{v}} 1.4$, with variable binding to other isoforms. These variations in targeting selectivity and affinity of each peptide for the different $\mathrm{Na}_{\mathrm{v}}$ isoforms constitute an important tool for distinguishing between different isoforms (Zhang et al., 2013). On the other hand are toxin peptides that modify $\mathrm{Na}_{\mathrm{V}}$ channel gating by interacting with the voltage sensors. Various classes of conotoxins interact with the voltage sensors of $\mathrm{Na}_{\mathrm{v}}$ channels and influence their gating properties. $\Delta$-conotoxins are ubiquitously expressed in a range of cone snail venoms and inhibit fast inactivation of channels. While the $\mu$-conotoxins are pore-blocking peptides, the $\mu \mathrm{O}$-conotoxins are gating modifiers that target the voltage sensors and inhibit channel opening (Daly et al., 2004; Zorn et al., 2006; Leipold et al., 2007). MO-conotoxins were evaluated for their pain-relieving activity and found to be anti-nociceptive in animal models of pain (Teichert et al., 2012).

Several spider toxins are in pre-clinical development stage as antagonists of $\mathrm{Na}_{\mathrm{v}} 1.7$, an attractive target for development of non-opiod pain medication. Protoxin-II (ProTX-II), derived from the tarantula Thrixopelma pruriens, inhibits channel activation by shifting to positive potentials the voltage dependence of channel activation. Using ProTX-II as a scaffold, a highly potent and selective $\mathrm{Na}_{\mathrm{v}} 1.7$ blocking peptide (JNJ63955918) has been developed, the effect of which mirrors features of the $\mathrm{Na}_{\mathrm{v}}$ 1.7-null phenotype (Flinspach et al., 2017). Another venom peptide, huwentoxin IV, is derived from the Chinese bird-eating spider Selenocosmia huwena (Peng et al., 2002). This peptide preferentially inhibits $\mathrm{Na}_{\mathrm{v}} 1.7$ by binding one of the four VSDs of the channel, making it more selective as compared to the local anesthetics that bind the conserved channel pore (Ragsdale et al., 1996; Xiao et al., 2008, 2011). Various mutational studies led to a triple mutant of huwentoxin IV (E1G, E4G, and Y33W) being developed with a very high potency toward $\mathrm{Na}_{\mathrm{v}} 1.7$ blocking (Revell et al., 2013).
$\mathrm{Na}_{\mathrm{v}} 1.5$ is expressed mainly in cardiac muscle, where it mediates fast depolarization phase of the cardiac action potential and is a target for class I anti-arrhythmic agents. JingzhaotoxinIII (from the Chinese tarantula Chilobrachys jingzhao) selectively inhibits the activation of $\mathrm{Na}_{\mathrm{v}} 1.5$ in heart cells (IC50 $350 \mathrm{nM}$ ), but not $\mathrm{Na}_{\mathrm{v}}$ neuronal subtypes (Rong et al., 2011).

Sea anemones are another source of $\mathrm{Na}_{\mathrm{v}}$-targeting peptides. Some key toxins are ATX-II (from Anemonia sulcata), AFT-II (from Anthopleura fuscoviridis) and Bc-III (from Bunodosoma caissarum). ATX-II strongly affects $\mathrm{Na}_{\mathrm{v}} 1.1$ and $\mathrm{Na}_{\mathrm{v}} 1.2$, while AFT-II affects $\mathrm{Na}_{\mathrm{v}} 1.4$ and $\mathrm{Na}_{\mathrm{v}} 1.5$. Given that these two differ in a single amino acid (ATX-II $\rightarrow \mathrm{K} 36 \mathrm{~A} \rightarrow \mathrm{AFTII}$ ), indicates that the lysine at position 36 is important for the very strong effects of ATX-II on $\mathrm{Na}_{\mathrm{v}} 1.1 / 2$ channels (Oliveira et al., 2004; Moran et al., 2009).

\section{VENOM PEPTIDES TARGETING VOLTAGE-GATED CALCIUM CHANNELS}

Voltage-gated calcium channels $\left(\mathrm{Ca}_{\mathrm{V}}\right)$ facilitate cellular calcium influx in response to membrane depolarization. They regulate hormone secretion, neurotransmitter release, propagation of cardiac action potential, muscle contraction and gene expression in different cell types (Catterall, 2011).

Similar to the $\mathrm{Na}_{\mathrm{V}}$ channels, the $\alpha 1$ subunit of $\mathrm{Ca}_{\mathrm{v}}$ channels is organized in four homologous domains (I-IV), each containing six TM segments (S1-S6). The S1-S4 segments constitute the voltage sensor, while S5-S6 constitute the pore. Auxiliary subunits usually associate with $\alpha 1$, regulating channel expression and function. $\mathrm{Ca}_{\mathrm{v}}$ channels are grouped into various types based on their electrophysiological and pharmacological properties and tissue distribution - L-type $\left(\mathrm{Ca}_{\mathrm{v}} 1\right.$ subfamily: $\left.\mathrm{Ca}_{\mathrm{v}} 1.1-\mathrm{Ca}_{\mathrm{v}} 1.4\right)$; P/Q-, N-, and R-types ( $\mathrm{Ca}_{\mathrm{v}} 2.1, \mathrm{Ca}_{\mathrm{v}} 2.2$ and $\mathrm{Ca}_{\mathrm{v}} 2.3$, respectively) and T-type $\left(\mathrm{Ca}_{\mathrm{v}} 3\right.$ subfamily: $\left.\mathrm{Ca}_{\mathrm{v}} 3 \cdot 1-\mathrm{Ca}_{\mathrm{v}} 3.3\right)$. Venom toxins have played a vital role in the discovery of, and in deciphering the structure and function of, many $\mathrm{Ca}_{\mathrm{v}}$ channels. Chief among them are the $\omega$-conotoxins and $\omega$-agatoxins.

$\Omega$-conotoxins are $\sim 24-30$ residues in length and contain three intramolecular disulfide bonds. They target $\mathrm{Ca}_{\mathrm{v}}$ channels via blocking the ion pore. $\Omega$-conotoxin GVIA, from the venom of Conus geographus, was the first of the $\omega$-conotoxins to be isolated and characterized (Kerr and Yoshikami, 1984; Olivera et al., 1985). Studies with GVIA showed inhibition of $\mathrm{Ca}^{2+}$ entry (voltage-activated), and GVIA was a powerful probe to explore the presynaptic terminal, linking $\mathrm{Ca}_{\mathrm{v}}$ (N-type) channels to neurotransmitter release and synaptic transmission (Kerr and Yoshikami, 1984; Olivera et al., 1984). Molecular identity of the $\mathrm{N}$-type and L-type channel subunit composition was determined using GVIA binding (Williams et al., 1992).

Subsequent to GVIA, many other $\omega$-conotoxins were identified. One of the most prominent ones is MVIIA, from the Magician's cone snail, Conus magus (Olivera et al., 1987), which was tested and developed as a therapeutic agent against pain. Ziconotide $\left(\right.$ Prialt $^{\circledR}$ ) has been clinically approved for the treatment of severe chronic pain associated with cancer and neuropathies, and is currently the only venom peptide drug 
targeting a voltage-gated ion channel $\left(\mathrm{Ca}_{\mathrm{v}} 2.2\right)$ that is in clinical use (Miljanich, 2004). A more selective $\omega$-conotoxin, CVID, was isolated from Conus catus (Lewis et al., 2000), and was being developed as leconotide for pain treatment. However, it failed clinical trials due to adverse side-effects (Kolosov et al., 2010).

Spider toxin $\omega$-agatoxin IVA, a gating modifier toxin isolated from Agelenopsis aperta, specifically targets P/Q-type channels (Pringos et al., 2011), and was used to study the channel subunit composition (McEnery et al., 1991; Witcher et al., 1995).

\section{CONCLUDING REMARKS}

Given that there are many species whose toxic venom are yet to be fully explored, the collection of venom-derived peptides to be discovered is immense. Also, with the advent of technology in drug design, based on currently available toxin peptides, new drugs will be developed into more stable and selective biologics. While venomous species developed toxins to incapacitate prey and predators, and envenomation is a public health hazard for us humans, the toxins have proven to be an excellent source of research and therapeutic tools.

\section{REFERENCES}

Abbas, N., Belghazi, M., Abdel-Mottaleb, Y., Tytgat, J., Bougis, P. E., and MartinEauclaire, M.-F. (2008). A new Kaliotoxin selective towards Kv1.3 and Kv1.2 but not Kv1.1 channels expressed in oocytes. Biochem. Biophys. Res. Commun. 376, 525-530. doi: 10.1016/j.bbrc.2008.09.033

Abdel-Mottaleb, Y., Vandendriessche, T., Clynen, E., Landuyt, B., Jalali, A., Vatanpour, H., et al. (2008). OdK2, a Kv1.3 channel-selective toxin from the venom of the Iranian scorpion Odonthobuthus doriae. Toxicon 51, 1424-1430. doi: 10.1016/j.toxicon.2008.03.027

Adams, M. E., Bindokas, V. P., Hasegawa, L., and Venema, V. J. (1990). Omegaagatoxins: novel calcium channel antagonists of two subtypes from funnel web spider (Agelenopsis aperta) venom. J. Biol. Chem. 265, 861-867.

Agnew, W. S., Levinson, S. R., Brabson, J. S., and Raftery, M. A. (1978). Purification of the tetrodotoxin-binding component associated with the voltage-sensitive sodium channel from Electrophorus electricus electroplax membranes. Proc. Natl. Acad. Sci. U.S.A. 75, 2606-2610. doi: 10.1073/pnas.75.6.2606

Alexander, S. P. H., Striessnig, J., Kelly, E., Marrion, N. V., Peters, J. A., Faccenda, E., et al. (2017). The concise guide to pharmacology 2017/18: voltage-gated ion channels. Br. J. Pharmacol. 174, S160-S194. doi: 10.1111/bph.13884

Armstrong, C. M., Bezanilla, F., and Rojas, E. (1973). Destruction of sodium conductance inactivation in squid axons perfused with pronase. J. Gen. Physiol. 62, 375-391. doi: 10.1085/jgp.62.4.375

Bagdáany, M., Batista, C. V. F., Valdez-Cruz, N. A., Somodi, S., de la Vega, R. C. R., Licea, A. F., et al. (2005). Anuroctoxin, a new scorpion toxin of the $\alpha-\mathrm{KTx} 6$ subfamily, is highly selective for Kv1.3 over IKCal ion channels of human T lymphocytes. Mol. Pharmacol. 67, 1034-1044. doi: 10.1124/mol.104.007187

Bartok, A., Toth, A., Somodi, S., Szanto, T. G., Hajdu, P., Panyi, G., et al. (2014). Margatoxin is a non-selective inhibitor of human Kv1.3 K+ channels. Toxicon 87, 6-16. doi: 10.1016/j.toxicon.2014.05.002

Beneski, D. A., and Catterall, W. A. (1980). Covalent labeling of protein components of the sodium channel with a photoactivable derivative of scorpion toxin. Proc. Natl. Acad. Sci. U.S.A. 77, 639-643. doi: 10.1073/pnas.77.1.639

Bhattacharjee, P., and Bhattacharyya, D. (2014). Therapeutic use of snake venom components: a voyage from ancient to modern India. Mini. Rev. Org. Chem. 11, 45-54. doi: 10.2174/1570193X1101140402101043

Bindokas, V. P., and Adams, M. E. (1989). w-Aga-I: a presynaptic calcium channel antagonist from venom of the funnel web spider, Agelenopsis aperta. J. Neurobiol. 20, 171-188. doi: 10.1002/neu.480200402

\section{AUTHOR CONTRIBUTIONS}

All authors listed have made a substantial, direct and intellectual contribution to the work, and approved it for publication.

\section{FUNDING}

SB has received funding from the People Programme (Marie Curie Actions) of the European Union's Seventh Framework Programme (FP7/2007-2013) under REA grant agreement no 608765. The authors also acknowledge support from Singapore Ministry of Education Academic Research Fund Tier 2 (MOE2016-T2-2-032) and Lee Kong Chian School of Medicine, Nanyang Technological University Singapore Start-Up Grant to Prof. George K. Chandy.

\section{ACKNOWLEDGMENTS}

The authors thank Prof. George K. Chandy and Dr. Jeff Chang for helpful discussions.

Bosmans, F., Rash, L., Zhu, S., Diochot, S., Lazdunski, M., Escoubas, P. T., et al. (2006). Four novel tarantula toxins as selective modulators of voltage-gated sodium channel subtypes. Mol. Pharmacol. 69, 419-429. doi: 10.1124/mol.105. 015941

Cahalan, M. D., and Chandy, K. G. (2009). The functional network of ion channels in T lymphocytes. Immunol. Rev. 231, 59-87. doi: 10.1111/j.1600-065X.2009. 00816.x

Candia, S., Garcia, M. L., and Latorre, R. (1992). Mode of action of iberiotoxin, a potent blocker of the large conductance $\mathrm{Ca}^{2+}$ )-activated $\mathrm{K}^{+}$channel. Biophys. J. 63, 583-590. doi: 10.1016/S0006-3495(92)81630-2

Carbone, E., Wanke, E., Prestipino, G., Possani, L. D., and Maelicke, A. (1982). Selective blockage of voltage-dependent $\mathrm{K}+$ channels by a novel scorpion toxin. Nature 296, 90-91. doi: 10.1038/296090a0

Cardoso, F. C., Dekan, Z., Rosengren, K. J., Erickson, A., Vetter, I., Deuis, J. R., et al. (2015). Identification and characterization of ProTx-III [ -TRTX-Tpla], a new voltage-gated sodium channel inhibitor from venom of the tarantula Thrixopelma pruriens. Mol. Pharmacol. 88, 291-303. doi: 10.1124/mol.115. 098178

Castañeda, O., Sotolongo, V., Amor, A. M., Stöcklin, R., Anderson, A. J., Harvey, A. L., et al. (1995). Characterization of a potassium channel toxin from the Caribbean sea anemone Stichodactyla helianthus. Toxicon 33, 603-613. doi: 10.1016/0041-0101(95)00013-C

Castle, N. A. (2003). Maurotoxin: a potent inhibitor of intermediate conductance $\mathrm{Ca}^{2+}$-activated potassium channels. Mol. Pharmacol. 63, 409-418. doi: 10.1124/ mol.63.2.409

Castle, N. A., and Strong, P. N. (1986). Identification of two toxins from scorpion (Leiurus quinquestriatus) venom which block distinct classes of calciumactivated potassium channel. FEBS Lett. 209, 117-121. doi: 10.1016/00145793(86)81095-X

Catterall, W. A. (2011). Voltage-gated calcium channels. Cold Spring Harb. Perspect. Biol. 3:a003947. doi: 10.1101/cshperspect.a003947

Chahine, M., Plante, E., and Kallen, R. G. (1996). Sea anemone toxin (ATX II) modulation of heart and skeletal muscle sodium channel $\alpha$-subunits expressed in tsA201 cells. J. Membr. Biol. 152, 39-48. doi: 10.1007/s002329900083

Chang, S., Bajaj, S., and Chandy, K. (2018). ShK toxin: history, structure and therapeutic applications for autoimmune diseases. WikiJ. Sci. 1:3. doi: 10.15347/ wjs/2018.003

Chen, H., Lu, S. Q., Leipold, E., Gordon, D., Hansel, A., and Heinemann, S. H. (2002). Differential sensitivity of sodium channels from the central and 
peripheral nervous system to the scorpion toxins Lqh-2 and Lqh-3. Eur. J. Neurosci. 16, 767-770. doi: 10.1046/j.1460-9568.2002.02142.x

Chi, V., Pennington, M. W., Norton, R. S., Tarcha, E. J., Londono, L. M., Sims-Fahey, B., et al. (2012). Development of a sea anemone toxin as an immunomodulator for therapy of autoimmune diseases. Toxicon 59, 529-546. doi: 10.1016/j.toxicon.2011.07.016

Chuan, T., Ruixin, Z., Lixin, Z., Tianyi, Q., Zhiwei, C., and Tingguo, K. (2013). Potassium channels: structures, diseases, and modulators. Chem. Biol. Drug Des. 83, 1-26. doi: 10.1111/cbdd.12237

Chuang, R. S., Jaffe, H., Cribbs, L., Perez-Reyes, E., and Swartz, K. J. (1998). Inhibition of T-type voltage-gated calcium channels by a new scorpion toxin. Nat. Neurosci. 1, 668-674. doi: 10.1038/3669

Cordeiro Mdo, N., de Figueiredo, S. G., Valentim, A., do, C., Diniz, C. R., von Eickstedt, V. R. D., et al. (1993). Purification and amino acid sequences of six Tx3 type neurotoxins from the venom of the Brazilian "armed" spider Phoneutria Nigriventer (keys.). Toxicon 31, 35-42. doi: 10.1016/0041-0101(93) 90354-L

Cotton, J., Crest, M., Bouet, F., Alessandri, N., Gola, M., Forest, E., et al. (1997). A potassium-channel toxin from the sea anemone Bunodosoma granulifera, an inhibitor for Kv1 channels. Revision of the amino acid sequence, disulfidebridge assignment, chemical synthesis, and biological activity. Eur. J. Biochem. 244, 192-202. doi: 10.1111/j.1432-1033.1997.00192.x

Crest, M., Jacquet, G., Gola, M., Zerrouk, H., Benslimane, A., Rochat, H., et al. (1992). Kaliotoxin, a novel peptidyl inhibitor of neuronal BK-type $\mathrm{Ca}^{2+}$. activated $\mathrm{K}^{+}$channels characterized from Androctonus mauretanicus venom. J. Biol. Chem. 267, 1640-1647. doi: 10.2106/JBJS.F.00758

Daly, N. L., Ekberg, J. A., Thomas, L., Adams, D. J., Lewis, R. J., and Craik, D. J. (2004). Structures of $\mu \mathrm{O}$-conotoxins from Conus marmoreus: inhibitors of tetrodotoxin (ttx)-sensitive and ttx-resistant sodium channels in mammalian sensory neurons. J. Biol. Chem. 279, 25774-25782. doi: 10.1074/ jbc.M313002200

de Weille, J. R., Schweitz, H., Maes, P., Tartar, A., and Lazdunski, M. (1991). Calciseptine, a peptide isolated from black mamba venom, is a specific blocker of the L-type calcium channel. Proc. Natl. Acad. Sci. U.S.A. 88, 2437-2440. doi: $10.1073 /$ pnas.88.6.2437

Deuis, J. R., Dekan, Z., Wingerd, J. S., Smith, J. J., Munasinghe, N. R., Bhola, R. F., et al. (2017). Pharmacological characterisation of the highly Na v 1.7 selective spider venom peptide Pn3a. Sci. Rep. 7:40883. doi: 10.1038/srep40883

Diochot, S., Drici, M.-D., Moinier, D., Fink, M., and Lazdunski, M. (1999). Effects of phrixotoxins on the Kv4 family of potassium channels and implications for the role of I(to1) in cardiac electrogenesis. Br. J. Pharmacol. 126, 251-263. doi: 10.1038/sj.bjp.0702283

Diochot, S., Schweitz, H., Béress, L., and Lazdunski, M. (1998). Sea anemone peptides with a specific blocking activity against the fast inactivating potassium channel Kv3.4. J. Biol. Chem. 273, 6744-6749. doi: 10.1074/jbc.273.12.6744

Dobrev, D., Friedrich, A., Voigt, N., Jost, N., Wettwer, E., Christ, T., et al. (2005). The G protein-gated potassium current IK,ACh is constitutively active in patients with chronic atrial fibrillation. Circulation 112, 3697-3706. doi: 10. 1161/CIRCULATIONAHA.105.575332

Doupnik, C. A. (2017). Venom-derived peptides inhibiting Kir channels: past, present, and future. Neuropharmacology 127, 161-172. doi: 10.1016/j. neuropharm.2017.07.011

Dutertre, S., and Lewis, R. J. (2010). Use of venom peptides to probe ion channel structure and function. J. Biol. Chem. 285, 13315-13320. doi: 10.1074/jbc.R109. 076596

Ekberg, J., Jayamanne, A., Vaughan, C. W., Aslan, S., Thomas, L., Mould, J., et al. (2006). muO-conotoxin MrVIB selectively blocks Nav1.8 sensory neuron specific sodium channels and chronic pain behavior without motor deficits. Proc. Natl. Acad. Sci. U.S.A. 103, 17030-17035. doi: 10.1073/pnas.0601819103

Ertel, E. A., Warren, V. A., Cohen, C. J., Smith, M. M., Adams, M. E., and Griffin, P. R. (1994). Type III $\omega$-agatoxins: a family of probes for similar binding sites on L- and N-type calcium channels. Biochemistry 33, 5098-5108. doi: 10.1021/ bi00183a013

Escoubas, P., Diochot, S., Célérier, M.-L., Nakajima, T., and Lazdunski, M. (2002). Novel tarantula toxins for subtypes of voltage-dependent potassium channels in the Kv2 and Kv4 subfamilies. Mol. Pharmacol. 62, 48-57. doi: 10.1124/mol. 62.1 .48
Flinspach, M., Xu, Q., Piekarz, A. D., Fellows, R., Hagan, R., Gibbs, A., et al. (2017). Insensitivity to pain induced by a potent selective closed-state Nav1.7 inhibitor. Sci. Rep. 7:39662. doi: 10.1038/srep39662

Gajewiak, J., Azam, L., Imperial, J., Walewska, A., Green, B. R., Bandyopadhyay, P. K., et al. (2014). A disulfide tether stabilizes the block of sodium channels by the conotoxin O -GVIIJ. Proc. Natl. Acad. Sci. U.S.A. 111, 2758-2763. doi: 10.1073/pnas.1324189111

Gao, B., Peigneur, S., Tytgat, J., and Zhu, S. (2010). A potent potassium channel blocker from Mesobuthus eupeus scorpion venom. Biochimie 92, 1847-1853. doi: 10.1016/j.biochi.2010.08.003

Garcia, M. L., Garcia-Calvo, M., Hidalgo, P., Lee, A., and MacKinnon, R. (1994). Purification and characterization of three inhibitors of voltage-dependent $\mathrm{K}^{+}$ channels from Leiurus quinquestriatus var. hebraeus Venom. Biochemistry 33, 6834-6839. doi: 10.1021/bi00188a012

Garcia, M. L., Knaus, H. G., Munujos, P., Slaughter, R. S., and Kaczorowski, G. J. (1995). Charybdotoxin and its effects on potassium channels. Am. J. Physiol. 269, C1-C10. doi: 10.1152/ajpcell.1995.269.1.C1

Garcia-Calvo, M., Leonard, R. J., Novick, J., Stevens, S. P., Schmalhofer, W., Kaczorowski, G. J., et al. (1993). Purification, characterization, and biosynthesis of margatoxin, a component of Centruroides margaritatus venom that selectively inhibits voltage-dependent potassium channels. J. Biol. Chem. 268, 18866-18874. doi: 10.1371/journal.pntd.0005212

Garcia-Valdes, J., Zamudio, F. Z., Toro, L., and Possan, L. D. (2001). Slotoxin, $\alpha \mathrm{KTx} 1.11$, a new scorpion peptide blocker of MaxiK channels that differentiates between $\alpha$ and $\alpha+\beta$ ( $\beta 1$ or $\beta 4$ ) complexes. FEBS Lett. 505, 369-373. doi: 10. 1016/S0014-5793(01)02791-0

Ghanshani, S., Wulff, H., Miller, M. J., Rohm, H., Neben, A., Gutman, G. A., et al. (2000). Up-regulation of the IKCal potassium channel during T-cell activation: molecular mechanism and functional consequences. J. Biol. Chem. 275, 37137-37149. doi: 10.1074/jbc.M003941200

Goldstein, S. A., Bayliss, D. A., Kim, D., Lesage, F., Plant, L. D., and Rajan, S. (2005). International union of pharmacology. LV. nomenclature and molecular relationships of two-p potassium channels. Pharmacol. Rev. 57, 527-540. doi: 10.1124/pr.57.4.12

Grissmer, S., Nguyen, A. N., Aiyar, J., Hanson, D. C., Mather, R. J., Gutman, G. A., et al. (1994). Pharmacological characterization of five cloned voltage-gated $\mathrm{K}^{+}$ channels, types Kv1.1, 1.2, 1.3, 1.5, and 3.1, stably expressed in mammalian cell lines. Mol. Pharmacol. 45, 1227-1234.

Hartshorne, R. P., and Catterall, W. A. (1981). Purification of the saxitoxin receptor of the sodium channel from rat brain. Proc. Natl. Acad. Sci. U.S.A. 78, 4620-4624. doi: 10.1073/pnas.78.7.4620

Hashimoto, N., Yamashita, T., and Tsuruzoe, N. (2006). Tertiapin, a selective IKACh blocker, terminates atrial fibrillation with selective atrial effective refractory period prolongation. Pharmacol. Res. 54, 136-141. doi: 10.1016/j. phrs.2006.03.021

Hibino, H., Inanobe, A., Furutani, K., Murakami, S., Findlay, I., and Kurachi, Y. (2010). Inwardly rectifying potassium channels: their structure, function, and physiological roles. Physiol. Rev. 90, 291-366. doi: 10.1152/physrev.00021.2009

Hidalgo, P., and MacKinnon, R. (1995). Revealing the architecture of a $\mathrm{K}^{+}$channel pore through mutant cycles with a peptide inhibitor. Science 268, 307-310. doi: $10.1126 /$ science. 7716527

Hille, B. (1971). The permeability of the sodium channel to organic cations in myelinated nerve. J. Gen. Physiol. 58, 599-619. doi: 10.1085/jgp.58. 6.599

Hille, B. (1975). Ionic selectivity, saturation, and block in sodium channels. A fourbarrier model. J. Gen. Physiol. 66, 535-560. doi: 10.1085/jgp.66.5.535

Hille, B. (1977). Local anesthetics: hydrophilic and hydrophobic pathways for the drug- receptor reaction. J. Gen. Physiol. 69, 497-515. doi: 10.1085/jgp.69. 4.497

Ho, K., Nichols, C. G., Lederer, W. J., Lytton, J., Vassilev, P. M., Kanazirska, M. V., et al. (1993). Cloning and expression of an inwardly rectifying ATP-regulated potassium channel. Nature 362, 31-38. doi: 10.1038/362031a0

Hugues, M., Romey, G., Duval, D., Vincent, J. P., and Lazdunski, M. (1982). Apamin as a selective blocker of the calcium-dependent potassium channel in neuroblastoma cells: voltage-clamp and biochemical characterization of the toxin receptor. Proc. Natl. Acad. Sci. U.S.A. 79, 1308-1312. doi: 10.1073/pnas. 79.4.1308 
Imredy, J. P., Chen, C., and MacKinnon, R. (1998). A snake toxin inhibitor of inward rectifier potassium channel ROMK1. Biochemistry 37, 14867-14874. doi: 10.1021/bi980929k

Jin, W., and Lu, Z. (1998). A novel high-affinity inhibitor for inward-rectifier K+ channels. Biochemistry 37, 13291-13299. doi: 10.1021/bi981178p

Jouirou, B., Mosbah, A., Visan, V., Grissmer, S., M’Barek, S., Fajloun, Z., et al. (2004). Cobatoxin 1 from Centruroides noxius scorpion venom: chemical synthesis, three-dimensional structure in solution, pharmacology and docking on $\mathrm{K}^{+}$channels. Biochem. J. 377, 37-49. doi: 10.1042/BJ20030977

Kalman, K., Pennington, M. W., Lanigan, M. D., Nguyen, A., Rauer, H., Mahnir, V., et al. (1998). Shk-Dap22, a potent Kv1.3-specific immunosuppressive polypeptide. J. Biol. Chem. 273, 32697-32707. doi: 10.1074/jbc.273.49.32697

Katz, B. (1949). Les constantes electriques de la membrane du muscle. Arch. Sci. Physiol. 3, 285-299.

Kerr, L. M., and Yoshikami, D. (1984). A venom peptide with a novel presynaptic blocking action. Nature 308, 282-284. doi: 10.1038/308282a0

Kimm, T., and Bean, B. P. (2014). Inhibition of A-type potassium current by the peptide toxin SNX-482. J. Neurosci. 34, 9182-9189. doi: 10.1523/JNEUROSCI. 0339- 14.2014

King, G. F. (2011). Venoms as a platform for human drugs: translating toxins into therapeutics. Expert Opin. Biol. Ther. 11, 1469-1484. doi: 10.1517/14712598. 2011.621940

Kolosov, A., Goodchild, C. S., and Cooke, I. (2010). CNSB004 (leconotide) causes antihyperalgesia without side effects when given intravenously: a comparison with ziconotide in a rat model of diabetic neuropathic pain. Pain Med. 11, 262-273. doi: 10.1111/j.1526-4637.2009.00741.x

Korolkova, Y. V., Kozlov, S. A., Lipkin, A. V., Pluzhnikov, K. A., Hadley, J. K., Filippov, A. K., et al. (2001). An ERG channel inhibitor from the scorpion Buthus eupeus. J. Biol. Chem. 276, 9868-9876. doi: 10.1074/jbc.M005973200

Koschak, A., Bugianesi, R. M., Mitterdorfer, J., Kaczorowski, G. J., Garcia, M. L., and Knaus, H.-G. (1998). Subunit composition of brain voltage-gated potassium channels determined by hongotoxin-1, a novel peptide derived from Centruroides limbatus Venom. J. Biol. Chem. 273, 2639-2644. doi: 10.1074/jbc. 273.5.2639

Kubo, Y., Baldwin, T. J., Nung Jan, Y., and Jan, L. Y. (1993). Primary structure and functional expression of a mouse inward rectifier potassium channel. Nature 362, 127-133. doi: 10.1038/362127a0

Kuzmenkov, A. I., Krylov, N. A., Chugunov, A. O., Grishin, E. V., and Vassilevski, A. A. (2016). Kalium: a database of potassium channel toxins from scorpion venom. Database 2016:baw056. doi: 10.1093/database/baw056

Lampe, R. A., Defeo, P. A., Davison, M. D., Young, J., Herman, J. L., Spreen, R. C., et al. (1993). Isolation and pharmacological characterization of omega-grammotoxin SIA, a novel peptide inhibitor of neuronal voltagesensitive calcium channel responses. Mol. Pharmacol. 44, 451-460.

Lebrun, B., Romi-Lebrun, R., Martin-Eauclaire, M. F., Yasuda, A., Ishiguro, M., Oyama, Y., et al. (1997). A four-disulphide-bridged toxin, with high affinity towards voltage-gated $\mathrm{K}^{+}$channels, isolated from Heterometrus spinnifer (Scorpionidae) venom. Biochem. J. 328, 321-327. doi: 10.1042/bj3280321

Lecomte, C., Ferrat, G., Fajloun, Z., Van Rietschoten, J., Rochat, H., MartinEauclaire, M. F., et al. (1999). Chemical synthesis and structure-activity relationships of Ts $\kappa$, a novel scorpion toxin acting on apamin-sensitive SK channel. J. Pept. Res. 54, 369-376. doi: 10.1034/j.1399-3011.1999. 00107.x

Leipold, E., De Bie, H., Zorn, S., Borges, A., Olivera, B. M., Terlau, H., et al. (2007). $\mu \mathrm{o}$-Conotoxins inhibit Navchannels by interfering with their voltage sensors in domain-2. Channels 1, 253-262. doi: 10.4161/chan.4847

Lewis, R. J., Nielsen, K. J., Craik, D. J., Loughnan, M. L., Adams, D. A., Sharpe, I. A., et al. (2000). Novel $\omega$-conotoxins from Conus catus discriminate among neuronal calcium channel subtypes. J. Biol. Chem. 275, 35335-35344. doi: 10. 1074/jbc.M002252200

Li, D., Chen, R., and Chung, S. H. (2016). Molecular dynamics of the honey bee toxin tertiapin binding to Kir3.2. Biophys. Chem. 219, 43-48. doi: 10.1016/j.bpc. 2016.09.010

Li, N., Wu, J. X., Ding, D., Cheng, J., Gao, N., and Chen, L. (2017). Structure of a pancreatic ATP-sensitive potassium channel. Cell 168, 101.e10-110.e10. doi: 10.1016/j.cell.2016.12.028

Liu, J., Ma, Y., Yin, S., Zhao, R., Fan, S., Hu, Y., et al. (2009). Molecular cloning and functional identification of a new $\mathrm{K}^{+}$channel blocker, LmKTx10, from the scorpion Lychas mucronatus. Peptides 30, 675-680. doi: 10.1016/j.peptides. 2008.11.015

Liu, Z., Dai, J., Chen, Z., Hu, W., Xiao, Y., and Liang, S. (2003). Isolation and characterization of hainantoxin-IV, a novel antagonist of tetrodotoxin-sensitive sodium channels from the Chinese bird spider Selenocosmia hainana. Cell. Mol. Life Sci. 60, 972-978. doi: 10.1007/s00018-003-2354-x

Long, S. B., Campbell, E. B., and Mackinnon, R. (2005). Voltage sensor of Kv1.2: structural basis of electromechanical coupling. Science 309, 903-908. doi: 10. $1126 /$ science. 1116270

Lu, Z. (2004). Mechanism of rectification in inward-rectifier $\mathrm{K}^{+}$channels. Annu. Rev. Physiol. 66, 103-129. doi: 10.1146/annurev.physiol.66.032102.150822

Lu, Z., and MacKinnon, R. (1997). Purification, characterization, and synthesis of an inward-rectifier $\mathrm{K}^{+}$channel inhibitor from scorpion venom. Biochemistry 36, 6936-6940. doi: 10.1021/bi9702849

Luna-Ramírez, K., Bartok, A., Restano-Cassulini, R., Quintero-Hernández, V., Coronas, F. I. V., Christensen, J., et al. (2014). Structure, molecular modeling, and function of the novel potassium channel blocker urotoxin isolated from the venom of the Australian Scorpion \&lt;em\&gt;Urodacus yaschenkoi\&lt;/em\&gt. Mol. Pharmacol. 86, 28-41. doi: 10.1124/mol.113. 090183

MacKinnon, R. (1991). Determination of the subunit stoichiometry of a voltage-activated potassium channel. Nature 350, 232-235. doi: 10.1038/350 $232 \mathrm{a} 0$

Maertens, C., Cuypers, E., Amininasab, M., Jalali, A., Vatanpour, H., and Tytgat, J. (2006). Potent modulation of the voltage-gated sodium channel Nav1.7 by OD1, a toxin from the scorpion Odonthobuthus doriae. Mol. Pharmacol. 70, 405-414. doi: 10.1124/mol.106. 022970

McDonough, S. I., Lampe, R. A., Keith, R. A., and Bean, B. P. (1997). Voltagedependent inhibition of $\mathrm{N}$ - and P-type calcium channels by the peptide toxin omega-grammotoxin-SIA. Mol. Pharmacol. 52, 1095-1104. doi: 10.1124/mol. 52.6.1095

McEnery, M. W., Snowman, A. M., Sharp, A. H., Adams, M. E., and Snyder, S. H. (1991). Purified omega-conotoxin GVIA receptor of rat brain resembles a dihydropyridine-sensitive L-type calcium channel. Proc. Natl. Acad. Sci. U.S.A. 88, 11095-11099. doi: 10.1243/09544062JMES1490

McQueen, C. (2017). Comprehensive Toxicology, 3rd Edn. Amsterdam: Elsevier Science.

Middleton, R. E., Warren, V. A., Kraus, R. L., Hwang, J. C., Liu, C. J., Dai, G., et al. (2002). Two tarantula peptides inhibit activation of multiple sodium channels. Biochemistry 41, 14734-14747. doi: 10.1021/bi026546a

Miljanich, G. (2004). Ziconotide: neuronal calcium channel blocker for treating severe chronic pain. Curr. Med. Chem. 11, 3029-3040. doi: 10.2174/ 0929867043363884

Minassian, N. A., Gibbs, A., Shih, A. Y., Liu, Y., Neff, R. A., Sutton, S. W., et al. (2013). Analysis of the structural and molecular basis of voltage-sensitive sodium channel inhibition by the spider toxin huwentoxin-IV ( $\mu$-TRTXHh2a). J. Biol. Chem. 288, 22707-22720. doi: 10.1074/jbc.M113.461392

Mintz, I. M., Venema, V. J., Swiderek, K. M., Lee, T. D., Bean, B. P., and Adams, M. E. (1992). P-type calcium channels blocked by the spider toxin $\omega$-Aga-IVA. Nature 355, 827-829. doi: 10.1038/355827a0

Moran, Y., Gordon, D., and Gurevitz, M. (2009). Sea anemone toxins affecting voltage-gated sodium channels - molecular and evolutionary features. Toxicon 54, 1089-1101. doi: 10.1016/j.toxicon.2009.02.028

Mouhat, S., Visan, V., Ananthakrishnan, S., Wulff, H., Andreotti, N., Grissmer, S., et al. (2005). $K(+)$ channel types targeted by synthetic OSK1, a toxin from Orthochirus scrobiculosus scorpion venom. Biochem. J. 385, 95-104. doi: 10. 1042/BJ20041379

Murray, J. K., Ligutti, J., Liu, D., Zou, A., Poppe, L., Li, H., et al. (2015). Engineering potent and selective analogues of GpTx-1, a tarantula venom peptide antagonist of the $\mathrm{Na}(\mathrm{V}) 1.7$ sodium channel. J. Med. Chem. 58, 2299-2314. doi: 10.1021/ jm $501765 \mathrm{v}$

Najet, S., Delavar, S., Imen, C., Saoussen, M., Hafedh, M., Lamia, B., et al. (2008). Hemitoxin, the first potassium channel toxin from the venom of the Iranian scorpion Hemiscorpius lepturus. FEBS J. 275, 4641-4650. doi: 10.1111/j.17424658.2008.06607.x

Newcomb, R., Szoke, B., Palma, A., Wang, G., Chen, X. H., Hopkins, W., et al. (1998). Selective peptide antagonist of the class E calcium channel from the 
venom of the tarantula Hysterocrates gigas. Biochemistry 37, 15353-15362. doi: 10.1021/bi981255g

Novello, J. C., Arantes, E. C., Varanda, W. A., Oliveira, B., Giglio, J. R., and Marangoni, S. (1999). TsTX-IV, a short chain four-disulfide-bridged neurotoxin from Tityus serrulatus venom which acts on $\mathrm{Ca}^{2+}$-activated $\mathrm{K}^{+}$channels. Toxicon 37, 651-660. doi: 10.1016/S0041-0101(98)00206-2

Ohkubo, T., Yamazaki, J., and Kitamura, K. (2010). Tarantula Toxin ProTx-I differentiates between human t-type voltage-gated $\mathrm{Ca}^{2+}$ channels Cav3.1 and Cav3.2. J. Pharmacol. Sci. 112, 452-458. doi: 10.1254/jphs.09356FP

Oliveira, J. S., Redaelli, E., Zaharenko, A. J., Cassulini, R. R., Konno, K., Pimenta, D. C., et al. (2004). Binding specificity of sea anemone toxins to Nav 1.1-1.6 sodium channels. Unexpected contributions from differences in the IV/S3-S4 outer loop. J. Biol. Chem. 279, 33323-33335. doi: 10.1074/jbc.M404344200

Olivera, B. M., Cruz, L. J., de Santos, V., LeCheminant, G. W., Griffin, D., Zeikus, R., et al. (1987). Neuronal calcium channel antagonists. Discrimination between calcium channel subtypes using omega-conotoxin from Conus magus venom. Biochemistry 26, 2086-2090. doi: 10.1021/bi00382a004

Olivera, B. M., Gray, W. R., Zeikus, R., McIntosh, J. M., Varga, J., Rivier, J., et al. (1985). Peptide neurotoxins from fish-hunting cone snails. Science 230, 1338-1343. doi: 10.1126/science.4071055

Olivera, B. M., McIntosh, J. M., Cruz, L. J., Gray, W. R., and Luque, F. A. (1984). Purification and sequence of a presynaptic peptide toxin from Conus geographus Venom. Biochemistry 23, 5087-5090. doi: 10.1021/bi00317a001

Olivera, B. M., Miljanich, G. P., Ramachandran, J., and Adams, M. E. (1994). Calcium channel diversity and neurotransmitter release: the $\omega$-Conotoxins and $\omega$-Agatoxins. Annu. Rev. Biochem. 63, 823-867. doi: 10.1146/annurev.bi.63. 070194.004135

Olivera, B. M., Rivier, J., Clark, C., Ramilo, C. A., Corpuz, G. P., Abogadie, F. C., et al. (1990). Diversity of Conus neuropeptides. Science 249, 257-263. doi: 10.1126/science. 2165278

Orts, D. J. B., Peigneur, S., Madio, B., Cassoli, J. S., Montandon, G. G., Pimenta, A. M. C., et al. (2013). Biochemical and electrophysiological characterization of two sea anemone type 1 potassium toxins from a geographically distant population of Bunodosoma caissarum. Mar. Drugs 11, 655-679. doi: 10.3390/ md11030655

Payandeh, J., Scheuer, T., Zheng, N., and Catterall, W. A. (2011). The crystal structure of a voltage-gated sodium channel. Nature 475, 353-358. doi: 10.1038/ nature 10238

Pedarzani, P., D’Hoedt, D., Doorty, K. B., Wadsworth, J. D. F., Joseph, J. S., Jeyaseelan, K., et al. (2002). Tamapin, a venom peptide from the Indian red scorpion (Mesobuthus tamulus) that targets small conductance $\mathrm{Ca}^{2+}$-activated $\mathrm{K}^{+}$channels and after hyperpolarization currents in central neurons. J. Biol. Chem. 277, 46101-46109. doi: 10.1074/jbc.M206465200

Peng, K., Shu, Q., Liu, Z., and Liang, S. (2002). Function and solution structure of huwentoxin-IV, a potent neuronal tetrodotoxin (TTX)-sensitive sodium channel antagonist from Chinese bird spider Selenocosmia huwena. J. Biol. Chem. 277, 47564-47571. doi: 10.1074/jbc.M204063200

Pennington, M. W., Byrnes, M. E., Zaydenberg, I., Khaytin, I., De Chastonay, J., Krafte, D. S., et al. (1995). Chemical synthesis and characterization of ShK toxin: a potent potassium channel inhibitor from a sea anemone. Int. J. Pept. Protein Res. 46, 354-358. doi: 10.1111/j.1399-3011.1995.tb01068.x

Pringos, E., Vignes, M., Martinez, J., and Rolland, V. (2011). Peptide neurotoxins that affect voltage-gated calcium channels: a close-up on $\omega$-agatoxins. Toxins 3 , 17-42. doi: 10.3390/toxins3010017

Pucca, M. B., Cerni, F. A., Cordeiro, F. A., Peigneur, S., Cunha, T. M., Tytgat, J., et al. (2016). Ts8 scorpion toxin inhibits the Kv4.2 channel and produces nociception in vivo. Toxicon 119, 244-252. doi: 10.1016/j.toxicon.2016. 06.014

Ragsdale, D. S., McPhee, J. C., Scheuer, T., and Catterall, W. A. (1996). Common molecular determinants of local anesthetic, antiarrhythmic, and anticonvulsant block of voltage-gated $\mathrm{Na}^{+}$channels. Proc. Natl. Acad. Sci. U.S.A. 93, 92709275. doi: 10.1073/pnas.93.17.9270

Rahnama, S., Deuis, J. R., Cardoso, F. C., Ramanujam, V., Lewis, R. J., Rash, L. D., et al. (2017). The structure, dynamics and selectivity profile of a $\mathrm{NaV} 1.7$ potency-optimised huwentoxin-IV variant. PLoS One 12:e173551. doi: 10.1371/journal.pone.0173551

Rauer, H., Lanigan, M. D., Pennington, M. W., Aiyar, J., Ghanshani, S., Cahalan, M. D., et al. (2000). Structure-guided transformation of charybdotoxin yields an analog that selectively targets $\mathrm{Ca}^{2+}$-activated over voltage-gated $\mathrm{K}^{+}$channels. J. Biol. Chem. 275, 1201-1208. doi: 10.1074/jbc.275.2.1201

Redaelli, E., Cassulini, R. R., Silva, D. F., Clement, H., Schiavon, E., Zamudio, F. Z., et al. (2010). Target promiscuity and heterogeneous effects of tarantula venom peptides affecting $\mathrm{Na}^{+}$and $\mathrm{K}^{+}$ion channels. J. Biol. Chem. 285, 4130-4142. doi: 10.1074/jbc.M109.054718

Revell, J. D., Lund, P. E., Linley, J. E., Metcalfe, J., Burmeister, N., Sridharan, S., et al. (2013). Potency optimization of Huwentoxin-IV on hNav1.7: a neurotoxin TTX-S sodium-channel antagonist from the venom of the Chinese bird-eating spider Selenocosmia huwena. Peptides 44, 40-46. doi: 10.1016/j.peptides.2013. 03.011

Robertson, B., and Owen, D. G. (1993). Pharmacology of a cloned potassium channel from mouse brain (MK-1) expressed in CHO cells: effects of blockers and an "inactivation peptide". Br. J. Pharmacol. 109, 725-735. doi: 10.1111/j. 1476-5381.1993.tb13634.x

Romi-Lebrun, R., Lebrun, B., Martin-Eauclaire, M. F., Ishiguro, M., Escoubas, P., Wu, F. Q., et al. (1997). Purification, characterization, and synthesis of three novel toxins from the Chinese scorpion Buthus martensi, which act on $\mathrm{K}^{+}$ channels. Biochemistry 36, 13473-13482. doi: 10.1021/bi971044w

Rong, M., Chen, J., Tao, H., Wu, Y., Jiang, P., Lu, M., et al. (2011). Molecular basis of the tarantula toxin jingzhaotoxin-III ( -TRTX-Cj1) interacting with voltage sensors in sodium channel subtype Nav1.5. FASEB J. 25, 3177-3185. doi: 10.1096/fj.10-178848

Ryadh, K., Kamel, M., Marcel, C., Hervé, D., Razika, O., Marie-France, M., et al. (2018). Chemical synthesis and characterization of maurotoxin, a short scorpion toxin with four disulfide bridges that acts on $\mathrm{K}^{+}$channels. Eur. J. Biochem. 242, 491-498. doi: 10.1111/j.1432-1033.1996.0491r.x

Sanguinetti, M. C., Johnson, J. H., Hammerland, L. G., Kelbaugh, P. R., Volkmann, R. A., Saccomano, N. A., et al. (1997). Heteropodatoxins: peptides isolated from spider venom that block Kv4.2 potassium channels. Mol. Pharmacol. 51, 491-498.

Sarrah, M., Amor, M., Guillaume, S., Ziad, F., Timoteo, O., Hervé, R., et al. (2003). Synthesis and characterization of Pi4, a scorpion toxin from Pandinus imperator that acts on $\mathrm{K}^{+}$channels. Eur. J. Biochem. 270, 3583-3592. doi: 10.1046/j.1432-1033.2003.03743.x

Schmalhofer, W. A., Calhoun, J., Burrows, R., Bailey, T., Kohler, M. G., Weinglass, A. B., et al. (2008). ProTx-II, a selective inhibitor of $\mathrm{Na}_{V} 1.7$ sodium channels, blocks action potential propagation in nociceptors. Mol. Pharmacol. 74, 14761484. doi: 10.1124/mol.108.047670

Sidach, S. S., and Mintz, I. M. (2002). Kurtoxin, a gating modifier of neuronal high- and low-threshold Ca channels. J. Neurosci. 22, 2023-2034. doi: 10.1523/ JNEUROSCI.22-06-02023.2002

Silva, A. O., Peigneur, S., Diniz, M. R. V., Tytgat, J., and Beirão, P. S. L. (2012). Inhibitory effect of the recombinant Phoneutria nigriventer Tx1 toxin on voltage-gated sodium channels. Biochimie 94, 2756-2763. doi: 10.1016/j.biochi. 2012.08.016

Swanson, R., Marshall, J., Smith, J. S., Williams, J. B., Boyle, M. B., Folander, K., et al. (1990). Cloning and expression of cDNA and genomic clones encoding three delayed rectifier potassium channels in rat brain. Neuron 4, 929-939. doi: 10.1016/0896-6273(90)90146-7

Swartz, K. J., and MacKinnon, R. (1995). An inhibitor of the Kv2.1 potassium channel isolated from the venom of a Chilean tarantula. Neuron 15, 941-949. doi: 10.1016/0896-6273(95)90184-1

Takacs, Z., Toups, M., Kollewe, A., Johnson, E., Cuello, L. G., Driessens, G., et al. (2009). A designer ligand specific for Kv1.3 channels from a scorpion neurotoxin-based library. Proc. Natl. Acad. Sci. U.S.A. 106, 22211-22216. doi: 10.1073/pnas.0910123106

Tao, H., Chen, J. J., Xiao, Y. C., Wu, Y. Y., Su, H. B., Li, D., et al. (2013). Analysis of the interaction of tarantula toxin jingzhaotoxin-III $(\beta$-TRTX-Cj1 $\alpha)$ with the voltage sensor of Kv2.1 uncovers the molecular basis for cross-activities on Kv2.1 and Nav1.5 channels. Biochemistry 52, 7439-7448. doi: 10.1021/ bi4006418

Tao, H., Chen, X., Deng, M., Xiao, Y., Wu, Y., Liu, Z., et al. (2016). Interaction site for the inhibition of tarantula Jingzhaotoxin-XI on voltage-gated potassium channel Kv2.1. Toxicon 124, 8-14. doi: 10.1016/j.toxicon.2016.10.019

Tarcha, E. J., Chi, V., Muñ;oz-Elías, E. J., Bailey, D., Londono, L. M., Upadhyay, S. K., et al. (2012). Durable pharmacological responses from the peptide ShK186, a specific Kv1.3 channel inhibitor that suppresses T cell mediators of 
autoimmune disease. J. Pharmacol. Exp. Ther. 342, 642-653. doi: 10.1124/jpet. 112.191890

Teichert, R. W., Raghuraman, S., Memon, T., Cox, J. L., Foulkes, T., Rivier, J. E., et al. (2012). Characterization of two neuronal subclasses through constellation pharmacology. Proc. Natl. Acad. Sci. U.S.A. 109, 12758-12763. doi: 10.1073/ pnas. 1209759109

Undheim, E. A. B., Mobli, M., and King, G. F. (2016). Toxin structures as evolutionary tools: using conserved $3 \mathrm{D}$ folds to study the evolution of rapidly evolving peptides. BioEssays 38, 539-548. doi: 10.1002/bies.201500165

Utkin, Y. N. (2015). Animal venom studies: current benefits and future developments. World J. Biol. Chem. 6, 28-33. doi: 10.4331/wjbc.v6.i2.28

Vandenberg, J. I., Perry, M. D., Perrin, M. J., Mann, S. A., Ke, Y., and Hill, A. P. (2012). hERG $\mathrm{K}^{+}$channels: structure, function, and clinical significance. Physiol. Rev. 92, 1393-1478. doi: 10.1152/physrev.00036.2011

Varga, Z., Gurrola-Briones, G., Papp, F., Rodríguez de la Vega, R. C., PedrazaAlva, G., Tajhya, R. B., et al. (2012). Vm24, a natural immunosuppressive peptide, potently and selectively blocks Kv1.3 Potassium Channels of Human T Cells. Mol. Pharmacol. 82, 372-382. doi: 10.1124/mol.112.078006

Vetter, I., Dekan, Z., Knapp, O., Adams, D. J., Alewood, P. F., and Lewis, R. J. (2012). Isolation, characterization and total regioselective synthesis of the novel Mo-conotoxin MfVIA from Conus magnificus that targets voltage-gated sodium channels. Biochem. Pharmacol. 84, 540-548. doi: 10.1016/j.bcp.2012.05.008

Walsh, K. (2011). Targeting GIRK channels for the development of new therapeutic agents. Front. Pharmacol. 2:64. doi: 10.3389/fphar.2011.00064

Wang, G., Long, C., Liu, W., Xu, C., Zhang, M., Li, Q., et al. (2018). Novel sodium channel inhibitor from leeches. Front. Pharmacol. 9:186. doi: 10.3389/fphar. 2018.00186

Wang, J., Shen, B., Guo, M., Lou, X., Duan, Y., Cheng, X. P., et al. (2005). Blocking effect and crystal structure of natrin toxin, a cysteine-rich secretory protein from Naja atra venom that targets the BKCa channel. Biochemistry 44, 10145-10152. doi: 10.1021/bi050614m

Wang, X., Umetsu, Y., Gao, B., Ohki, S., and Zhu, S. (2015). Mesomartoxin, a new Kv1.2-selective scorpion toxin interacting with the channel selectivity filter. Biochem. Pharmacol. 93, 232-239. doi: 10.1016/j.bcp.2014.12.002

Whorton, M. R., and MacKinnon, R. (2011). Crystal structure of the mammalian GIRK2 $\mathrm{K}^{+}$channel and gating regulation by G-proteins, PIP(2) and sodium. Cell 147, 199-208. doi: 10.1016/j.cell.2011.07.046

Williams, M. E., Brust, P. F., Feldman, D. H., Patthi, S., Simerson, S., Maroufi, A., et al. (1992). Structure and functional expression of an $\omega$-conotoxin-sensitive human N-type calcium channel. Science 257, 389-395. doi: 10.1126/science. 1321501

Wilson, M. J., Yoshikami, D., Azam, L., Gajewiak, J., Olivera, B. M., Bulaj, G., et al. (2011). -Conotoxins that differentially block sodium channels NaV1.1 through 1.8 identify those responsible for action potentials in sciatic nerve. Proc. Natl. Acad. Sci. U.S.A. 108, 10302-10307. doi: 10.1073/pnas.11070 27108

Witcher, D. R., De Waard, M., Liu, H., Pragnell, M., and Campbell, K. P. (1995). Association of native $\mathrm{Ca}^{2+}$ channel $\beta$ subunits with the $\alpha 1$ subunit interaction domain. J. Biol. Chem. 270, 18088-18093. doi: 10.1074/jbc.270.30. 18088

Xiao, Y., Bingham, J. P., Zhu, W., Moczydlowski, E., Liang, S., and Cummins, T. R. (2008). Tarantula huwentoxin-IV inhibits neuronal sodium channels by binding to receptor site 4 and trapping the domain II voltage sensor in the closed configuration. J. Biol. Chem. 283, 27300-27313. doi: 10.1074/jbc. M708447200

Xiao, Y., Jackson, J. O., Liang, S., and Cummins, T. R. (2011). Common molecular determinants of tarantula huwentoxin-IV inhibition of $\mathrm{Na}^{+}$channel voltage sensors in domains II and IV. J. Biol. Chem. 286, 27301-27310. doi: 10.1074/ jbc.M111.246876

Yan, L., and Adams, M. E. (2000). The spider toxin $\omega$-Aga IIIA defines a high affinity site neuronal high voltage-activated calcium channels. J. Biol. Chem. 275, 21309-21316. doi: 10.1074/jbc.M000212200

Yan, L., Herrington, J., Goldberg, E., Dulski, P. M., Bugianesi, R. M., Slaughter, R. S., et al. (2005). \&lt;em\&gt;Stichodactyla helianthus\&lt;/em\&gt; peptide, a pharmacological tool for studying Kv3.2 channels. Mol. Pharmacol. 67, 15131521. doi: 10.1124/mol.105.011064

Yang, S., Xiao, Y., Kang, D., Liu, J., Li, Y., Undheim, E. A. B., et al. (2013). Discovery of a selective NaV1.7 inhibitor from centipede venom with analgesic efficacy exceeding morphine in rodent pain models. Proc. Natl. Acad. Sci. U.S.A. 110, 17534-17539. doi: 10.1073/pnas.1306285110

Yao, J., Chen, X., Li, H., Zhou, Y., Yao, L., Wu, G., et al. (2005). BmP09, a "long chain" scorpion peptide blocker of BK channels. J. Biol. Chem. 280, 14819-14828. doi: 10.1074/jbc.M412735200

Yellen, G. (2002). The voltage-gated potassium channels and their relatives. Nature 419, 35-42. doi: 10.1038/nature00978

Yuan, C., Liao, Z., Zeng, X., Dai, L., Kuang, F., and Liang, S. (2007). JingzhaotoxinXII, a gating modifier specific for Kv4.1 channels. Toxicon 50, 646-652. doi: 10.1016/j.toxicon.2007.05.009

Zaharenko, A. J., Schiavon, E., Ferreira, W. A., Lecchi, M., Freitas, J. C., De Richardson, M., et al. (2012). Characterization of selectivity and pharmacophores of type 1 sea anemone toxins by screening seven Navsodium channel isoforms. Peptides 34, 158-167. doi: 10.1016/j.peptides.2011. 07.008

Zeng, X., Deng, M., Lin, Y., Yuan, C., Pi, J., and Liang, S. (2007). Isolation and characterization of Jingzhaotoxin- $\mathrm{V}$, a novel neurotoxin from the venom of the spider Chilobrachys jingzhao. Toxicon 49, 388-399. doi: 10.1016/j.toxicon.2006. 10.012

Zerrouk, H., Mansuelle, P., Benslimane, A., Rochat, H., and Martin-Eauclaire, M. F. (1993). Characterization of a new leiurotoxin I-like scorpion toxin. PO5from Androctonus mauretanicus mauretanicus. FEBS Lett. 320, 189-192. doi: 10.1016/0014-5793(93)80583-G

Zhang, M. M., Wilson, M. J., Azam, L., Gajewiak, J., Rivier, J. E., Bulaj, G., et al. (2013). Co-expression of $\mathrm{NaV} \beta$ subunits alters the kinetics of inhibition of voltage-gated sodium channels by pore-blocking $\mu$-conotoxins. Br. J. Pharmacol. 168, 1597-1610. doi: 10.1111/bph. 12051

Zhu, S., Peigneur, S., Gao, B., Lu, X., Cao, C., and Tytgat, J. (2012). Evolutionary diversification of Mesobuthus a-scorpion toxins affecting sodium channels. Mol. Cell. Proteomics 11:M111.012054. doi: 10.1074/mcp.M111.012054

Zorn, S., Leipold, E., Hansel, A., Bulaj, G., Olivera, B. M., Terlau, H., et al. (2006). The $\mu \mathrm{O}$-conotoxin MrVIA inhibits voltage-gated sodium channels by associating with domain-3. FEBS Lett. 580, 1360-1364. doi: 10.1016/j.febslet. 2006.01.057

Conflict of Interest Statement: The authors declare that the research was conducted in the absence of any commercial or financial relationships that could be construed as a potential conflict of interest.

Copyright (c) 2019 Bajaj and Han. This is an open-access article distributed under the terms of the Creative Commons Attribution License (CC BY). The use, distribution or reproduction in other forums is permitted, provided the original author(s) and the copyright owner(s) are credited and that the original publication in this journal is cited, in accordance with accepted academic practice. No use, distribution or reproduction is permitted which does not comply with these terms. 